\title{
ANALISIS PENGARUH EPS, ROE, DPS DAN ROA TERHADAP HARGA SAHAM PERUSAHAAN PERDAGANGAN BESAR YANG TERDAFTAR DI BURSA EFEK INDONESIA (BEI) PERIODE 2013-2016
}

\author{
Yang Yang \\ Program Studi Magister Manajemen Universitas Tarumanagara \\ yang2x@ymail.com
}

Masuk : 14-06-2019, revisi : 22-08-2019 diterima untuk diterbitkan : 23-08-2019

\begin{abstract}
This study examines the effect of Earning Per Share (EPS), Return On Equity (ROE), Dividend Per Share (DPS) and Return On Asset (ROA) toward Stock Price. This research is used sampling technique is purposive sampling with criteria as follow (1) wholesale company which have go public and active traded in Indonesia Stock Exchange with period 2013-2016;(2) wholesale company that provide annual reports during 2013-2016;(3) wholesale company that still running their business during 2013-2016. Sample was acquired 24 wholesale company that's fulfill the criteria and this research is using secondary data that's obtained from www.idx.co.id. The method of analysis used in this research is regression analysis of data panel with the Fixed Effect Model method. The result of this research show that Earning Per Share (EPS), Return On Equity (ROE), and Return On Asset (ROA) partially have not significant effect on stock price of wholesale company while Dividend Per Share (DPS) have significant effect on stock price of wholesale company, however simultaneously have significant effect on stock price of wholesale company. Prediction capability from these variables towards stock price is indicated by adjusted R Squared $96.33 \%$ where the residues $3.67 \%$ is caused by other factor which not in this research.
\end{abstract}

Keywords : Earning Per Share (EPS), Return On Equity (ROE), Dividend Per Share (DPS), Return On Asset (ROA), Stock Price, Fixed Effect Model, Wholesale Company

Abstrak : Penelitian ini bertujuan untuk mengetahui pengaruh dari Earning Per Share (EPS), Return On Equity (ROE), Dividend Per Share (DPS) dan Return On Asset (ROA), terhadap Harga Saham. Dalam penelitian ini menggunakan teknik sampling purposive sampling dengan criteria sebagai berikut (1) perusahaan perdagangan besar yang telah go public dan aktif diperdagangkan di Bursa Efek Indonesia pada tahun 2013-2016; (2) perusahaan perdagangan besar yang menyediakan laporan keuangan tahunan 2013-2016;(3) perusahaan perdagangan besar yang tetap beroperasi pada 2013-2016. Sampel yang diperoleh sebanyak 24 perusahaan perdagangan besar yang memenuhi kriteria dan dalam penelitian ini menggunakan data sekunder yang di peroleh dari www.idx.co.id. Metode analisis yang digunakan dalam penelitian ini adalah regresi data panel dengan metode Fixed Effect Model. Hasil dari penelitian ini menunjukan bahwa Earning Per Share (EPS), Return On Equity (ROE), dan Return On Asset (ROA) tidak berpengaruh terhadap harga saham perusahaan perdagangan besar sedangkan Per Share (DPS) berpengaruh terhadap harga saham perusahaan perdagangan besar. Kemampuan memprediksi dari variabel yang diteliti terhadap harga saham ditunjukan oleh adjusted $R$ Squared sebesar $96.33 \%$ dimana sisanya sebesar 3,67\% disebabkan oleh variabel lain yang tidak diteliti dalam penelitian ini.

Kata Kunci : Earning Per Share (EPS), Return On Equity (ROE), Dividend Per Share (DPS), Return On Asset (ROA), Stock Price, Fixed Effect Model, Perusahaan Perdagangan Besar. 


\section{PENDAHULUAN}

Di era globalisasi sekarang ini menyebabkan semakin terbukanya perekonomian Indonesia terhadap perekonomian dunia. Perkembangan perekonomian dalam negeri ditandai dengan semakin banyaknya perusahaan dan lembaga keuangan yang didirikan untuk mendukung perekonomian di dalam tanah air. Perkembangan perekonomian saat ini tidak dapat dipisahkan dari pasar modal, pasar modal merupakan wadah untuk melakukan suatu mobilisasi dana dari para investor atau pemegang saham kepada suatu perusahaan yang telah go public yang di gunakan oleh perusahan untuk peningkatan modal usaha ataupun digunakan dengan tujuan untuk melakukan ekspansi usaha.

Sekarang ini telah banyak perusahaan yang telah melakukan go public di pasar modal, dengan banyaknya perusahaan yang telah melakukan go public, selaku calon pemegang saham ataupun investor harus dapat meneliti kondisi perusahaan sebelum memutuskan untuk menanamkan modal di suatu perusahaan. Prinsip pemegang saham atau investor dalam melakukan penanaman modal adalah mengharapkan return yang maksimal atas investasi yang dilakukannya pada suatu perusahaan, maka dari itu setiap calon investor atau pemegang saham harus mengetahui kondisi suatu perusahaan, terkhususnya pada kondisi keuangan perusahaan tersebut. Dengan melakukan penilitian pada kondisi suatu perusahaan, maka calon investor atau pemegang saham dapat memperoleh gambaran tentang kondisi suatu perusahaan dengan jelas sehingga dapat mengukur resiko yang akan terjadi serta return yang akan diterimanya di masa yang akan datang sebagai dasar pengambilan keputusan untuk melakukan investasi pada suatu perusahaan.

Sesuai dengan prinsip pemegang saham atau investor yaitu mengharapkan return yang maksimal, return saham perusahaan kepada para investor berupa capital gain yang merupakan selisih antara harga pasar periode sekarang dengan periode sebelumnya dan juga return saham berupa dividend yield yang dibagikan oleh perusahaan kepada semua investor atau pemegang saham perusahan. Dalam melakukan analisis mengenai return saham suatu perusahaan, diperlukan data - data dan informasi historis suatu perusahaan, dimana data dan informasi historis tersebut tercantum dalam annual report perusahaan tersebut. Annual report suatu perusahaan merupakan cerminan dari kinerja manajemen perusahaan sehingga secara tidak langsung digunakan calon investor atau pemegang saham untuk mengukur nilai dari suatu perusahaan.

Darmadji dan Fakhruddin (sebagaimana dikutip dari Abied, 2013), menyatakan bahwa indeks harga saham merupakan indikator yang menunjukkan pergerakan harga saham. Salah satu alat analisis yang dapat digunakan investor dalam mengevaluasi return saham serta harga saham adalah melalui analisis fundamental perusahaan dengan pendekatan ratio keuangannya seperti Earning per Share (EPS), Return On Equity (ROE), Dividen per Share (DPS), Return On Investment (ROI) atau pendekatan lain sebagai referensi dalam mengevaluasi return saham."

\section{TINJAUAN LITERATUR}

Tujuan seorang investor dalam melakukan kegiatan investasi dalam berbagai macam aset yaitu untuk meningkatkan kesejahteraan investor yang telah melakukan investasi. (Tandelilin, 2010). Dalam melakukan investasi seorang investor dapat mendapatkan sumber dana dari berbagai macam aset - aset yang dimiliki seperti tabungan maupun melakukan pinjaman dari pihak lain seperti bank. berikut :

Secara lebih khusus alasan investor melakukan suatu kegiatan investasi adalah sebagai

1. Untuk mendapatkan kehidupan yang lebih baik di masa datang. Seseorang yang bijaksana akan berpikir bagaiman meningkatkan taraf hidupnya dari waktu ke waktu atau setidaknya berusaha bagaimana mempertahankan tingkat pendapatannya yang ada sekarang agar tidak berkurang dimasa yang akan datang. 
2. Mengurangi tekanan inflasi. Dengan melakukan investasi dalam pemilikan perusahaan atau obyek lain, seseorang dapat menghindarkan diri dari resiko penurunan nilai kekayaan atau hak miliknya akibat pengaruh inflasi

3. Dorongan untuk menghemat pajak. Beberapa Negara di dunia banyak melakukan kebijakan yang bersifat mendorong tumbuhnya investasi di masyarakat melalui pemberian fasilitas perpajakan kepada masyarakat yang melakukan investasi pada bidang - bidang usaha tertentu (Tandelilin, 2010, p. 8-9)

Earning Per Share (EPS) menurut Kasmir (2008) adalah rasio yang digunakan untuk mengukur kesuksesan manajemen suatu perusahaan dalam menghasilkan keuntungan bagi para pemegang saham. Bagi para investor, informasi Earning Per Share (EPS) merupakan informasi dasar namun sangat penting dikarenakan bisa memberikan proyeksi akan pendapatan suatu perusahaan di masa yang akan datang.

ROE menurut Brigham dan Houston (2015) "measures the rate of return on common stockholders investment".(p.110) Menurut Reilly dan Brown (2012) “Return on Owner's Equity indicates the rate of return that management has earned on the capital provided by the owner after accounting for payment to all other capital suppliers". (p. 288)

Dividend Per Share (DPS) menurut Intan (sebagaimana dikutip dari Damayanti, Atmadja dan Adiputra, 2014) merupakan total dari dividen tunai yang dibagikan ke pemegang saham dibandingkan dengan jumlah saham beredar suatu perusahaan.

Return On Assets (ROA) menurut Tandelilin (2010) adalah ratio yang mengambarkan kemampuan aset perusahaan dalam menghasilkan laba bagi perusahaan.

Berdasarkan pada penelitian - penelitian lain sebelumnya, variabel - variabel yang mempengaruhi harga saham diantaranya adalah EPS dan DPS (Denies Pratianah Prabandaru dan Adhe Kusuma:2012), ROA (Ali Kesuma:2009), ROE (Rescyana Putri Hutami:2012). Hipotesis dalam penelitian ini adalah menguji pengaruh EPS, ROE, DPS dan ROA terhadap Harga saham perusahaan perdagangan besar periode 2013-2016 secara parsial maupun secara simultan.

\section{METODOLOGI PENELITIAN}

Penelitian yang dilakukan oleh peneliti adalah penelitian kuantitatif, dimana dalam melakukan penelitian data yang digunakan adalah data sekunder. Data yang menjadi sumber dasar penelitian merupakan data annual report perusahaan di bidang perdagangan besar yang tercatat di Bursa Efek Indonesia (BEI) periode 2013-2016

Populasi yang menjadi subyek dalam penelitian ini adalah perusahaan di bidang perdagangan besar yang tercatat di Bursa Efek Indonesia (BEI). Dalam penelitian ini pemilihan sampel penelitian menggunakan teknik sampling yaitu metode purposive sampling, yaitu pemilihan sampel perusahaan selama periode penelitian berdasarkan kriteria tertentu, dikarenakan untuk mempermudah penelitian karena banyaknya anggota populasi. Beberapa kriteria yang ditetapkan untuk memperoleh sampel adalah sebagai berikut:

a. Perusahaan bidang perdagangan besar yang telah go public di Bursa Efek Indonesia (BEI) pada waktu kurun penelitian (periode 2013-2016)

b. Tersedia data annual report selama kurun waktu penelitian (periode 2013-2016)

c. Perusahaan yang diteliti masih beroperasi pada periode waktu penelitian (periode 20132016)

Berdasarkan pada kriteria pengambilan sampel yang telah disebutkan maka jumlah sampel yang digunakan dalam penelitian ini adalah sebanyak 24 perusahaan. 
Model Regresi Data Panel untuk penelitian ini dirumuskan sebagai berikut :

$$
\mathrm{Y}=\alpha+\beta 1 \mathrm{X}_{1}+\beta 2 \mathrm{X}_{2}+\beta 3 \mathrm{X}_{3}+\beta 4 \mathrm{X}_{4}+\varepsilon
$$

Keterangan :

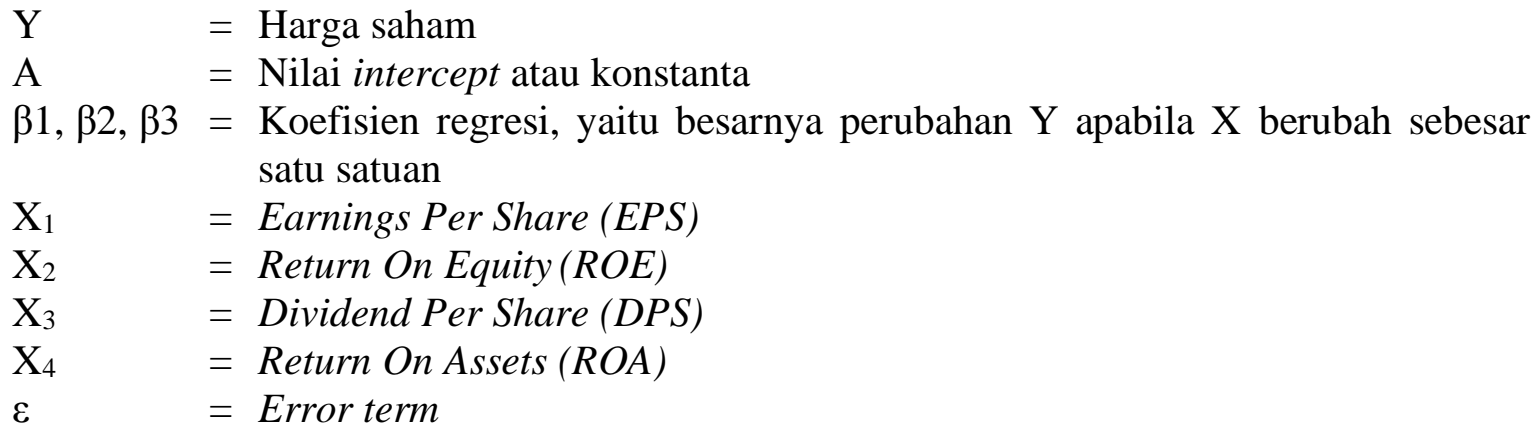

\section{ANALISIS DAN PEMBAHASAN}

Data penelitian yang digunakan adalah sebanyak 24 perusahaan yang semuanya bergerak dalam sektor perdagangan besar yang telah go public dan terdaftar pada Bursa Efek Indonesia (BEI) periode tahun 2013-2016 serta telah memenuhi kriteria sampel.

1. Berdasarkan Chow Test nilai Cross Section Chi-square adalah sebesar 0.0000 berada dibawah nilai alpha sebesar 0.05 sehingga $\mathrm{H} 1$ diterima maka model yang lebih tepat untuk digunakan dalam penelitian ini adalah model Fixed Effect Model dibandingkan dengan Common OLS Model.

2. Berdasarkan hasil Hausman Test yang dilakukan, nilai cross section random sebesar 0.0000 sehingga $\mathrm{H} 1$ diterima maka berarti bahwa model yang lebih tepat digunakan dalam penelitian ini adalah Fixed Effect Model dibandingkan dengan Random Effect Model

3. Berdasarkan Fixed Effect Model diperoleh persamaan regresi berganda sebagai berikut: $\mathrm{Y}=1812.785+0.130937 \mathrm{X}_{1}+82.02782 \mathrm{X}_{2}-9.723958 \mathrm{X}_{3}+468.1236 \mathrm{X}_{4}+\varepsilon$

4. Nilai koefisien regresi variabel $E P S\left(\mathrm{X}_{1}\right)$ adalah sebesar 0.130937 , Nilai koefisien regresi variabel $R O E\left(\mathrm{X}_{2}\right)$ sebesar 82.02782, Nilai koefisien regresi variabel DPS $\left(\mathrm{X}_{3}\right)$ adalah sebesar -9.723958, Nilai koefisien regresi variabel ROA $\left(\mathrm{X}_{4}\right)$ adalah sebesar 468.1236

5. Berdasarkan Fixed Effect Model nilai Prob. dari semua variabel independen adalah EPS : 0,5067; ROE : 0,7182; DPS : 0,0000 dan ROA : 0,4885 yang berarti DPS mempunyai pengaruh terhadap harga saham perusahaan perdagangan besar periode 2013-2016.

6. Berdasarkan Fixed Effect Model Nilai Prob uji F sebesar 0.0000. Sehingga, disimpulkan bahwa Earning Per Share (EPS), Return On Equity (ROE), Dividend Per Share (DPS), dan Return On Asset (ROA) secara simultan mempunyai pengaruh secara signifikan terhadap harga saham perusahaan perdagangan besar periode 2013-2016.

7. Nilai adjusted R-squared adalah sebesar 0.963348 yang berarti variabel Earnings Per Share (EPS), Return On Equity (ROE), Dividen Per Share (DPS), dan Return On Assets (ROA) mempunyai kontribusi dalam menjelaskan variabel harga saham sebesar $96.33 \%$ sedangkan sisanya sebesar 3,67\% dijelaskan oleh variabel lain yang tidak dijelaskan dalam penelitian ini.

\section{KESIMPULAN DAN SARAN}

Earnings Per Share (EPS) nilai Prob sebesar 0,5067, Return On Equity (ROE) nilai Prob sebesar 0,7182, dan Return On Assets (ROA) nilai Prob sebesar 0,4885 yang berarti secara parsial berpengaruh terhadap harga saham perusahaan perdagangan besar yang terdaftar di Bursa Efek Indonesia (BEI) periode 2013-2016. Dividen Per Share (DPS) nilai Prob sebesar 0,0000 yang berarti secara parsial berpengaruh terhadap harga saham perusahaan perdagangan besar yang terdaftar di Bursa Efek Indonesia (BEI) periode 2013-2016. Nilai Prob uji F sebesar 0.0000. sehingga, disimpulkan bahwa Earning Per Share (EPS), Return On Equity (ROE), 
Dividend Per Share (DPS), dan Return On Asset (ROA) secara simultan mempunyai pengaruh secara signifikan terhadap harga saham perusahaan perdagangan besar periode 2013-2016

Berdasarkan hasil penelitian ini, adapun penulis mempunyai saran untuk penelitian selanjutnya sebagai berikut :

1. Menambah pada periode penelitian.

2. Menambahkan jumlah variabel penelitian seperti Net Profit Margin (NPM), Debt to Equity Ratio (DER) dan sebagainya.

3. Menggunakan jenis klasifikasi industri perusahaan go public yang berbeda

Bagi Investor dan perusahaan, peneliti memiliki pendapat sebagai berikut :

1. Earnings Per Share (EPS), Return On Equity (ROE), Dividen Per Share (DPS), dan Return On Assets (ROA) perlu menjadi bahan pertimbangan untuk calon investor dalam melakukan investasi pada perusahaan perdagangan besar yang terdaftar di Bursa Efek Indonesia (BEI). Berdasarkan pada penelitian ini variabel Return On Assets (ROA) berpengaruh positif dan paling kuat terhadap variabel harga saham bila dibandingkan dengan variabel lain (Earnings Per Share (EPS), Return On Equity (ROE), dan Dividen Per Share (DPS)) sehingga Return On Assets (ROA) yang merupakan rasio yang menggambarkan kemampuan aset perusahaan yang diolah oleh manajemen perusahaan untuk mendapatkan laba untuk perusahaan. Hal ini merupakan hal yang penting dan perlu diperhatikan bagi investor, semakin tinggi ratio Return On Assets menunjukan tingginya kemampuan perusahaan dalam menghasilkan keuntungan bagi perusahaan, sehingga pasar akan percaya dengan prospek perusahaan kedepan-nya yang mungkin akan berdampak pada permintaan saham dan berimbas dengan naiknya harga saham dari perusahaan tersebut, hal ini pula berlaku sebaliknya.

\section{DAFTAR PUSTAKA}

Brigham, Eugene F., \& Houston, Joel F. (2015). Fundamentals of Financial Management $\left(8^{\text {th }}\right.$ ed.), USA : Cengage Learning.

Damayanti, Putu Ryan, Atmadja, Anantawikrama Tungga, dan Adiputra, I Made Pradana. (2014). PENGARUH DIVIDEND PER SHARE DAN EARNING PER SHARE PADA PERUSAHAAN INDUSTRI BARANG KONSUMSI YANG TERDAFTAR DI BURSA EFEK INDONESIA PERIODE 2010-2012 from Undiksha website : https://ejournal.undiksha.ac.id/index.php/S1ak/article/view/2406

Darmadji \& Fakhruddin, (2011). Pasar Modal di Indonesia, edisi 3, Jakarta : Salemba Empat.

Datu, Christian V. dan Maredesa, Djeini. (2017). PENGARUH DEVIDEND PER SHARE DAN EARNING PER SHARE TERHADAP HARGA SAHAM PADA PERUSAHAAN $G O$ PUBLIC DI BRUSA EFEK INDONESIA from Unsrat website : https://ejournal.unsrat.ac.id/index.php/gc/article/view/18696

Dewi, Aristya Putu Dina, dan Suaryana I.G.N.A (2013) PENGARUH EPS, DER, DAN PBV TERHADAP HARGA SAHAM from Udayana Website : https://ojs.unud.ac.id/index.php/Akuntansi/article/view/5924

Eduardus Tandelilin, MBA, CWM. (2010). "Portofolio dan Investasi", Edisi pertama, Yogyakarta : Kanisius.

Ehrhardt, Michael C,. \& Brigham, Eugene F. (2011). Financial Management Theory and Practice $\left(13^{\text {th }}\right.$ ed.), USA : Cengage Learning.

Ghozali, H. Imam, \& Ratmono, Dwi (2013). Analisis Multivariat dan Ekonometrika : Teori, Konsep dan Aplikasi dengan EVIEWS 8, Semarang : Undip.

Husainih, Achmad. (2012). PENGARUH VARIABEL RETURN ON ASSETS, RETURN ON EQUITY, NET PROFIT MARGIN DAN EARNING PER SHARE TERHADAP HARGA SAHAM PERUSAHAAN from Universitas Brawijaya Website : http://www.ejournalfia.ub.ac.id/index.php/profit/article/view/132 
Hutami, Reseyana Putri. (2012). PENGARUH DIVIDEND PER SHARE, RETURN ON EQUITY DAN NET PROFIT MARGIN TERHADAP HARGA SAHAM PERUSAHAAN INDUSTRI MANUFAKTUR YANG TERCATAT DI BURSA EFEK INDONESIA PERIODE 2006-2010 from UNY website : https://journal.uny.ac.id/index.php/nominal/article/view/1001

Kasmir. (2008) Analisis Laporan Keuangan. Depok : PT Raja Grafindo Persada

Kesuma, Ali. (2009). ANALISIS FAKTOR YANG MEMPENGARUHI STRUKTUR MODAL SERTA PENGARUHNYA TERHADAP HARGA SAHAM PERUSAHAAN REAL - ESTATE YANG GO PUBLIC DI BURSA EFEK INDONESIA from Petra website : http://ced.petra.ac.id/index.php/man/article/view/17743

Nachrowi, D., \& Hardius Usman. (2006). Pendekatan Populer dan Praktis Ekonometrika untuk Analisis Ekonomi dan Keuangan, Jakarta : Lembaga Penerbit Universitas Indonesia

Paramasivan, C. \& Subramanian, T. (2009). Financial Management New Delhi, India : New Age International.

Priatinah, Denies dan Kusuma, Prabandaru Adhe. (2012). PENGARUH RETURN ON INVESTMENT (ROI), EARNING PER SHARE (EPS) DAN DIVIDEN PER SHARE $(D P S)$ TERHADAP HARGA SAHAM PERUSAHAAN PERTAMBANGAN YANG TERDAFTAR DI BURSA EFEK INDONESIA (BEI) PERIODE 2008-2010 from UNY website : https://journal.uny.ac.id/index.php/nominal/article/view/998

Safitri, Abied Luthfi. (2013). PENGARUH EARNING PER SHARE, PRICE EARNING RATIO, RETURN ON ASSET, DEBT TO EQUITY RATIO DAN MARKET VALUE ADDED TERHADAP HARGA SAHAM DALAM KELOMPOK JAKARTA ISLAMIC INDEX from UNNES website

https://journal.unnes.ac.id/sju/index.php/maj/article/view/2479

Subiyantoro, Edi dan Andreani, Fransisca. (2003). Analisis Faktor - Faktor Yang Mempengaruhi Harga Saham (Kasus Perusahaan Jasa Perhotelan Yang Terdaftar Di Pasar Modal Indonesia) from Petra website : http://puslit.petra.ac.id/journals/management/

Utami, Sri Setyaningsih. (2005) PENGARUH RASIO KEUANGAN TERHADAP HARGA SAHAM (Studi pada Perusahaan Perbankan di Bursa Efek Jakarta) from Unistri website : http://ejurnal.unisri.ac.id/index.php/Manajemen/article/view/613

Weston, Fred, J. \& Thomas, E Copeland. (1999). Manajemen Keuangan Jilid 1, Terjemahan Jaka Wasama dan Krisbandono, Jakarta : Penerbit Bina Rupa Aksara.

Weygandt, Jerry J., Kieso, Donald E. \& Kimmel, Paul D. (2007). Accounting Principles $\left(8^{\text {th }}\right.$ ed.), USA : Wiley International 